\title{
New species and records in the genus Synagelides Strand in Bösenberg et Strand, 1906 (Aranei: Salticidae) from the Oriental region
}

\section{Новые виды и находки в роде Synagelides Strand in Bösenberg et Strand, 1906 (Aranei: Salticidae) из ориентальной области}

\author{
Dmitri V. Logunov \\ Амитрий В. Аогунов
}

The Manchester Museum, The University of Manchester, Oxford Road, Manchester M13 9PL, UK. Email: dmitri.v.logunov@manchester.ac.uk

KEY WORDS: diagnosis, new faunistic records, south Asia, south-east Asia, taxonomic comments.

КЛЮЧЕВЫЕ СЛОВА: диагноз, новые фаунистические находки, таксономические заметки, юго-восточная азия, южная азия.

ABSTRACT. Four new Synagelides species are diagnosed, described and illustrated: S. haoyai sp.n. $\left(\sigma^{7}\right)$ from Thailand, $S$. kochang sp.n. ( $\left.\sigma^{7}+\right)$ from Thailand, S. larisae sp.n. ( $\left.\sigma^{7}\right)$ from Indonesia, and $S$. munnar sp.n. $\left(\sigma^{7}\right)$ from India. New faunistic records are given for $S$. palpalis Żabka, 1985 (from Vietnam), S. palpaloides Peng, Tso et Li, 2002 (from Taiwan) and S. sumatranus Logunov et Hereward, 2006 (from Sumatra). Distribution of all the studied species is mapped.

How to cite this article: Logunov D.V. 2017. New species and records in the genus Synagelides Strand in Bösenberg et Strand, 1906 (Aranei: Salticidae) from the Oriental region // Arthropoda Selecta. Vol.26. No.4. P.315-322. doi: 10.15298/arthsel.26.4.06

PЕЗЮМЕ. Четыре новых вида Synagelides диагностированы, описаны и иллюстрированы: S. haoyai sp.n. $\left(\sigma^{7}\right)$ из Таиланда, S. kochang sp.n. ( $\sigma^{7}$ ) из Таиланда, $S$. larisae sp.n. $\left(\sigma^{7}\right)$ из Индонезии, и $S$. munnar sp.n. $\left(\sigma^{7}\right)$ из Индии. Новые фаунистические находки даны для S. palpalis Żabka, 1985 (из Вьетнама), S. palpaloides Peng, Tso et Li, 2002 (из Тайваня) и S. sumatranus Logunov et Hereward, 2006 (с Суматры). Распротранение всех изученных видов прокартировано.

\section{Introduction}

According to WSC [2017], the genus Synagelides contains 38 valid species, of which eight species (21\%) are known from the males, and 11 species $(29 \%)$ from the females. As pointed out by Logunov \& Hereward [2006], the assignment of some Synagelides species needs verification, as they are likely to belong to the genus Agorius Thorell, 1877. The more general problem of interrelationships between Agorius and Syn- agelides has not been scrutinized yet and is still in need of a thorough attention in the future (see also below under 'Discussion'). The main aims of the present work are (1) to describe four new species from Indonesia, Thailand and India, and (2) to provide new faunistic records for three other species; distribution of all the studied species is mapped (Map).

Specimens for this study were borrowed from or deposited in the following museums: MHNG - Museum d'historie naturelle, Gèneve, Switzerland (curator: P. Schwendinger); MMUE - The Manchester Museum, University of Manchester, UK (curator: D.V. Logunov); and ZMMU - Zoological Museum of the Moscow State University, Moscow, Russia (curator: K.G. Mikhailov).

Abbreviations used in the text: AME - anterior median eye, Fm - femur, Mt - metatarsus, PLE posterior lateral eye, $\mathrm{Tb}$ - tibia, $\mathrm{v}$ - ventral. For the leg spination the system adopted is that used by Ono [1988]. The sequence of leg segments in measurement data is as follows: femur + patella + tibia + metatarsus + tarsus (total). All measurements are in mm. For described species only references to the original descriptions or those with reliable illustrations are provided; complete reference lists for such species can be found in WSC [2017].

\section{Descriptions and faunistic notes}

\section{Synagelides haoyai sp.n.}

Figs 1-5, Map.

TYPES. Holotype $0^{7}$ (MHNG) from Thailand, NE Bangkok, Khao Yai National Park [c. $14^{\circ} 26^{\prime} 29^{\prime \prime} \mathrm{N}, 101^{\circ} 22^{\prime} 11^{\prime \prime} \mathrm{E}$ ], $750-800$ $\mathrm{m}$ a.s.1., 26.10-3.12.1985, Burckhardt and Löbl. - Paratype: THAILAND: $1 \sigma^{7}$ (MHNG), Hao Yai National Park, Khao Khico, $1150 \mathrm{~m}$ a.s.l., 28.11.1985, Burckhardt and Löbl. 


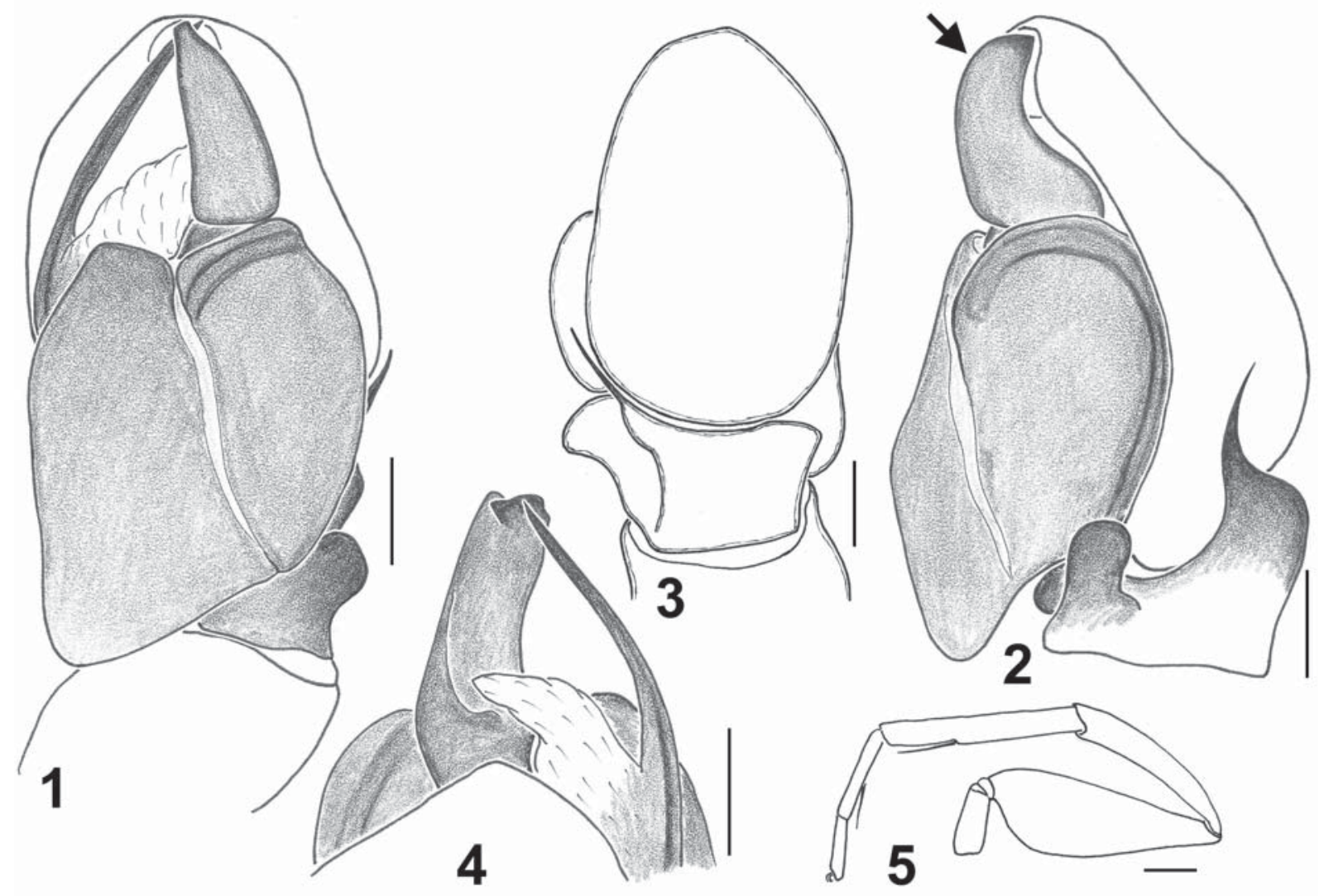

Figs 1-5. Copulatory organ and leg I of the paratype male of Synagelides haoyai sp.n. from Thailand: 1 - palp, ventral view; 2 ditto, retrolateral view; 3 - ditto, dorsal view; 4 - embolar division, dorsal view; 5 - left leg I, lateral view. Scale bars $=(1-4) 0.1 \mathrm{~mm}$, (5) $0.25 \mathrm{~mm}$

Рис. 1-5. Копулятивный орган и нога I самца-паратипа Synagelides haoyai sp.n. из Таиланда: 1 - пальпа, вид снизу; 2 - тоже, вид сзади-сбоку; 3 - тоже, вид сверху; 4 - эмболярный отдел, вид сверху; 5 — нога I, вид сбоку. Масштаб (1-4) 0,1 мм, (5) 0,25 мм.

ETYMOLOGY. The species name is a noun in apposition taken from the type locality: Khao Yai National Park in Thailand.

DIAGNOSIS. By the conformation of the male palp (Figs 1-4), the new species is most similar to that of $S$. kualaensis Logunov et Hereward, 2006 from Malaysia (see figs 28-30 in Logunov \& Hereward [2006]), but can be distinguished from it by the shape of the longer and narrower median apophysis, bent dorsad (arrowed in Fig. 2; almost square and not bent in S. kualaensis). See also comments under 'Diagnosis' of $S$. larisae sp.n. The female of $S$. haoyai sp.n. remains unknown.

DISTRIBUTION. Two localities in Thailand (Map).

DESCRIPTION. MALE (the holotype). Measurements. Carapace 1.58 long, 1.10 wide and 0.60 high at PLE. Ocular area: 1.11 long, 1.13 wide anteriorly and 1.15 wide posteriorly. Diameter of AME 0.40. Clypeus is not marked. Chelicera length 0.30. Abdomen 1.50 long, 0.85 wide. Length of leg segments: I $1.00+0.83+$ $0.78+0.40+0.25(3.26) ;$ II $0.88+0.43+0.71+0.80+$ 0.38 (2.29); III $0.70+0.30+0.48+0.58+0.30$ (2.36); IV $2.25+1.05+1.50+2.10+0.85$ (3.20). Leg formula I,IV,III,II. Leg spination: I: Tb v 0-0-1-2-1; Mt v 1-1. Remaining legs are without spines. Colora- tion (in alcohol). Carapace yellow, tinged with brown, with a shiny shagreen surface, sparsely covered with white recumbent scales; black around eyes. Sternum and chelicerae yellow. Endites and labium yellow, with white tips. Abdomen: dorsum and sides light brown, with a poorly-marked yellow transverse stripe in the centre, entirely covered with a shiny scutum; venter light yellow, with a shiny scutum consisting of two parts covering the areas before and after the epigastric furrow. Book-lungs and spinnerets light yellow. Leg I: Fm, Tb and the basal half of Mt yellow, tinged with brown; remaining legs light yellow. Palps yellow. Palpal structure as in Figs 1-4: ventral tibial apophysis short, knob-like; dorsal tibial apophysis claw-like, directed anterio-dorsad; functional tegulum pear-shaped; median apophysis alongated and tapered to its tip which is visibly bent dorsad; embolus straight, with a welldeveloped membranous basis.

Female unknown

\section{Synagelides kochang sp.n.}

Figs 6-11, Map.

TYPES. Holotype $\sigma^{7}$ (MHNG) from Thailand, Trat Prov., Ko Chang, west side $\left(12^{\circ} 03^{\prime} \mathrm{N}, 102^{\circ} 18^{\prime} \mathrm{E}\right), 50-200 \mathrm{~m}$ a.s.1., 2-23.12. 

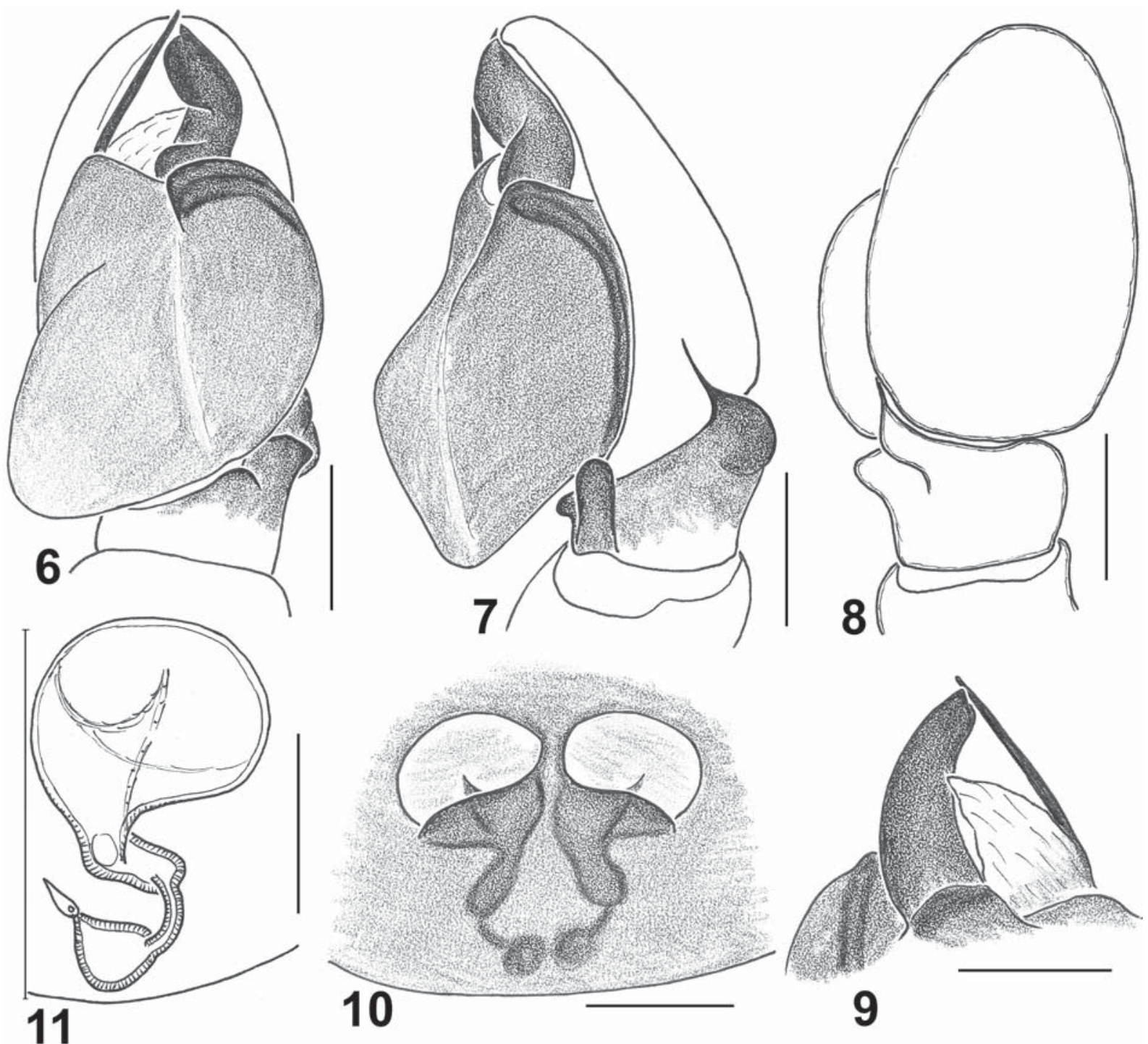

Figs 6-11. Copulatory organs of the holotype male (6-9) and paratype female $(10,11)$ of Synagelides kochang sp.n. from Thailand: 6 - palp, ventral view; 7 - ditto, retrolateral view; 8 - ditto, dorsal view; 9 - embolar division, dorsal view; 10 - epigyne, ventral view; 11 - spermatheca, dorsal view. Scale bars $=0.1 \mathrm{~mm}$.

Рис. 6-11. Копулятивные органы самца-голотипа (6-9) и самки-паратипа $(10,11)$ Synagelides kochang sp.n. из Таиланда: 6 пальпа, вид снизу; 7 - тоже, вид сзади-сбоку; 8 - тоже, вид сверху; 9 - эмболярный отдел, вид сверху, 10 - эпигина, вид снизу; 11 - сперматека, вид сверху. Масштаб 0,1 мм.

1999, A. Schulz. - Paratypes: 2 O$^{\top} \sigma^{\top}, 2$ 2 (MHNG), together with the holotype.

ETYMOLOGY. The species name is a noun in apposition taken from the type locality: Ko Chang in Trat Province of Thailand.

DIAGNOSIS. By the conformation of the male palp (Figs 6-9), the new species is most similar to those of S. kualaensis Logunov et Hereward, 2006 from Malaysia (see figs 28-30 in Logunov, Hereward [2006]) and S. haoyai sp.n. from Thailand (Figs 1-4), but can be distinguished from both by the shape of the twisted median apophysis bearing two ventral crests (Fig. 6) which are absent from the related species, and by the narrowest dorsal tibial apophysis (Fig. 7). See also comments under 'Diagnosis' of $S$. larisae sp.n. Of the described Synagelides females, those of $S$. kochang sp.n. and S. sumatranus are most similar (cf. Figs 10, 11 with figs 51-52 in Logunov, Hereward [2006]); they can easily be distinguished by the shape and position of the copulatory openings and the thickness of insemination ducts, which are visibly thicker in $S$. sumatranus.

DISTRIBUTION. The type locality only: Ko Chang in Trat Province of Thailand (Map).

DESCRIPTION. MALE (the holotype; strongly damaged, with the abdomen being detached from the carapace, and the following legs missing: right leg I and left legs III and IV). Measurements. Carapace 1.25 long, 
0.85 wide and 0.50 high at PLE. Ocular area: 0.80 long, 0.88 wide anteriorly and 0.90 wide posteriorly. Diameter of AME 0.50. Clypeus is not marked. Chelicera length 0.23 . Abdomen 1.25 long, 0.78 wide. Length of leg segments: I $0.73+0.50+0.55+0.35+0.23$ (2.36); II $0.50+0.28+0.30+0.33+0.23(1.64)$; III $0.50+0.23+0.30+0.43+0.23(1.69) ;$ IV $0.65+$ $0.30+0.48+0.55+0.25(2.23)$. Leg formula I,IV,III,II. Leg spination: I: Tb v 0-0-1; Mt v 0-2-1. Remaining legs are without spines. Coloration (in alcohol; based on a better preserved body of the paratype without legs). Carapace yellow, tinged with brown, with a shiny shagreed surface; the anterior half of the eye field brown and black around eyes. Sternum and chelicerae yellow. Endites and labium yellow, with white apexes. Abdomen: dorsum brownish-grey, with a transverse light yellow band in its centre (in some specimens, also in the rear end of dorsum), dorsum entirely covered with a brownish shiny scutum; sides and venter yellow, venter with a brownish shiny scutum consisting of two parts: one covering the area before the epigastric furrow, another - the central part of venter. Book-lung covers yellow, tinged with brown. Spinnerets light yellow. Leg I: Fm, distal end of Tb and Mt brownish, remaining segments yellow. Legs II-IV entirely yellow. Palps yellow, tinged with brown. Palpal structure as in Figs 6-9: ventral tibial apophysis short and obtuse; dorsal thin, claw-like, directed anteriad; functional tegulum pear-shaped; median apophysis thick and twisted, bearing two visible ventral crests (proximal and distal); embolus straight, with a well-developed membranous basis.

Female (the paratype). Measurements. Carapace 1.40 long, 0.98 wide and 0.53 high at PLE. Ocular area: 0.95 long, 1.03 wide anteriorly and 1.03 wide posteriorly. Diameter of AME 0.34. Clypeus is not marked. Chelicera length 0.23. Abdomen 1.40 long, 0.85 wide. Length of leg segments: I $0.83+0.55+$ $0.59+0.30+0.23(2.50) ;$ II $0.55+0.33+0.33+0.40+$ 0.28 (1.89); III $0.55+0.28+0.35+0.48+0.25(1.91)$; IV $0.78+0.38+0.60+0.63+0.28$ (2.67). Leg formula IV,I,III,II. Leg spination: I: Tb v 0-0-1-1; Mt v 0-2-1. Remaining legs are without spines. Coloration (in alcohol), as described for the male but lighter and differs as follows: there are no scuta on dorsum and venter; white transverse bands of dorsum are wider and better marked, plus there is an additional light yellow transverse band at the rear end of dorsum; all legs and palps light yellow, with no colour markings. Epigyne and spermathecae as in Figs 10, 11: epigyne with large ovoid fossae in which the large, round copulatory openings are situated; insemination ducts S-shaped, with wide, funnel-shaped entrances; small, pear-shaped primary spermathecae directed to each other.

\section{Synagelides larisae sp.n.} Figs 12-16, Map.

TYPE. Holotype $\sigma^{7}$ (MHNG) from Indonesia, Sumatra, Lampung Prov., Bukit Barisan Selatan National Park, road Krui - Liwa
(= Liva), c. $2 \mathrm{~km}$ of Kubuprahu [= Kubu Perahu (c. $5^{\circ} 04^{\prime} 15.4^{\prime \prime} \mathrm{S}$, $\left.\left.104^{\circ} 03^{\prime} 09.0^{\prime \prime} \mathrm{E}\right)\right], 480-540 \mathrm{~m}$ a.s.1., disturbed evergreen rain forest and secondary forest, 4.03.2000, P. Schwendinger.

ETYMOLOGY. The species is dedicated to the author's wife, Mrs Larisa B. Logunova.

DIAGNOSIS. By the conformation of the male palp (Figs 12-15), the new species is most similar to those of S. kualaensis Logunov et Hereward, 2006 from Malaysia (see figs 28-30 in Logunov \& Hereward [2006]), S. haoyai sp.n. from Thailand (Figs 1-4) and S. kochang sp.n. (Figs 6-9), but can easily be distinguished from all by the S-shaped and twisted median apophysis with a pointed tip (arrowed in Fig. 12; not pointed in the related species), and the straight dorsal tibial apophysis (claw-like in the related species). The female of $S$. larisae sp.n. remains unknown.

DISTRIBUTION. The type locality only: Sumatra, Bukit Barisan Selatan National Park (Map).

DESCRIPTION. Male (the holotype is damaged, with the detached left leg I and two legs missing: left leg II and right leg IV). Measurements. Carapace 1.60 long, 1.14 wide and 0.65 high at PLE. Ocular area: 1.08 long, 1.15 wide anteriorly and 1.15 wide posteriorly. Diameter of AME 0.40. Clypeus is not marked. Chelicera length 0.33. Abdomen 1.53 long, 0.93 wide. Length of leg segments: I $0.98+0.80+0.80+0.43+$ 0.28 (3.29); II $0.75+0.38+0.48+0.50+0.28$ (2.39); III $0.73+0.35+0.48+0.60+0.28(2.44)$; IV $0.93+$ $0.43+0.78+0.80+0.33(3.27)$. Leg formula I,IV,III,II. Leg spination: I: Tb v 0-0-2-1; Mt v 1-1ap. Remaining legs are without spines. Coloration (in alcohol). Carapace yellow, tinged with brown, with a shiny shagreen surface, sparsely covered with white recumbent scales; black around eyes. Sternum and chelicerae yellow. Endites and labium yellow, with white tips. Abdomen: dorsum and sides light brown, with a yellow transverse stripe, entirely covered with a shiny scutum; venter light yellow, with a shiny scutum consisting of two parts covering both the areas before and after the epigastric furrow. Book-lungs and spinnerets light yellow. Leg I: Fm, Tb and the basal half of Mt yellow, tinged with brown; remaining legs light yellow. Palps yellow. Palpal structure as in Figs 12-15: ventral tibial apophysis short, obtuse and slightly bent laterad; dorsal tibial apophysis long and straight, directed anteriad; functional tegulum pear-shaped; median apophysis thick, twisted, with a pointed tip directed dorsad; embolus straight, with a well-developed membranous basis.

Female unknown.

\section{Synagelides munnar sp.n. Figs 17-21, Map.}

TYPES. Holotype $\sigma^{7}$ (MHNG) from India, Kerala, Cardamom Hills [c. $10^{\circ} 06^{\prime} 30.7^{\prime \prime} \mathrm{N}, 77^{\circ} 05^{\prime} 24.0^{\prime \prime} \mathrm{E}$ ], c. $13 \mathrm{~km} \mathrm{NE}$ of Munnar, $1900 \mathrm{~m}$ a.s.1., siefting in the forest, 26.11.1972, C. Besuchet \& I. Löbl.

ETYMOLOGY. The species name is a noun in apposition taken from the type locality: Munnar town in the Western Ghats mountain range (Kerala, India). 

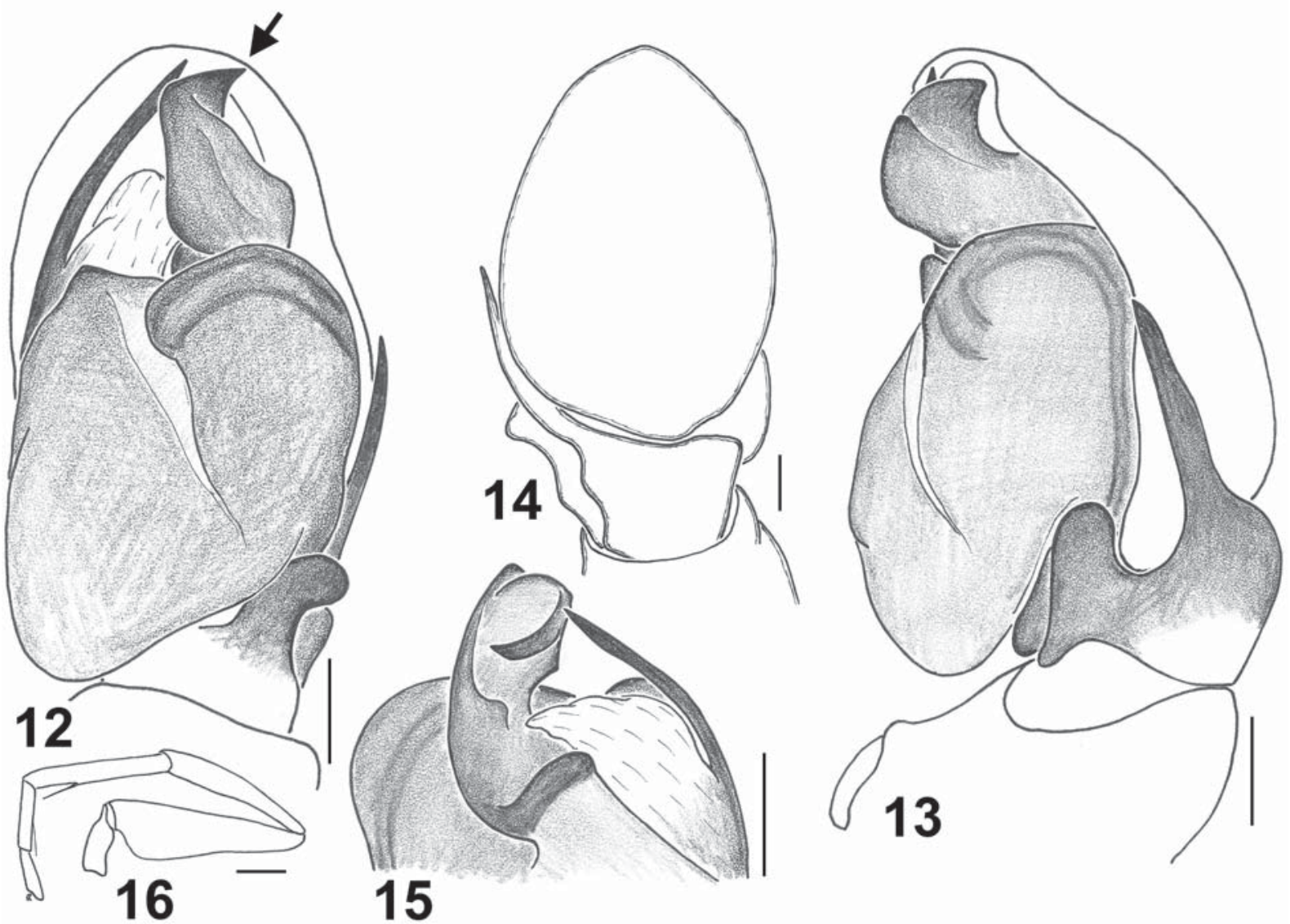

Figs 12-16. Copulatory organ and leg I of the holotype male of Synagelides larisae sp.n. from Indonesia: 12 - palp, ventral view; 13 ditto, retrolateral view; 14 - ditto, dorsal view; 15 - embolar division, dorsal view; 16 - left leg I, lateral view. Scale bars $=(12-15)$ 0.1 $\mathrm{mm}$, (16) $0.25 \mathrm{~mm}$.

Рис. 12-16. Копулятивный орган и нога I самца-голотипа Synagelides larisae sp.n. из Индонезии: 12 - пальпа, вид снизу; 13 тоже, вид сзади-сбоку; 14 - тоже, вид сверху; 15 - эмболярный отдел, вид сверху; 16 - нога I, вид сбоку. Масштаб (12-15) 0,1 мм, (16) 0,25 мм.

DIAGNOSIS. The male of S. munnar sp.n. (Figs 17-21) differs from those of all the described Synagelides species known to the author in having the corkscrew-like embolus and the narrow, blade-shaped median apophysis. Besides, the cymbium has a distalmedian cut through which the round base of the embolus is visible (Fig. 20); it is a unique feature among all the described Synagelides species. The female of $S$. munnar sp.n. remains unknown.

DISTRIBUTION. The type locality only: the vicinity of Munnar town, the Western Ghats mountain range in Kerala, India (Map).

DESCRIPTION. Male. Measurements. Carapace 1.30 long, 0.93 wide and 0.49 high at PLE. Ocular area: 0.80 long, 0.90 wide anteriorly and 0.93 wide posteriorly. Diameter of AME 0.31. Clypeus is not marked. Chelicera length 0.33. Abdomen 1.25 long, 0.78 wide. Length of leg segments: I $0.78+0.43+$ $0.56+0.38+0.25(2.40) ;$ II $0.55+0.33+0.33+0.38+$ 0.20 (1.79); III $0.58+0.28+0.35+0.48+0.25(1.94)$; IV $0.75+0.40+0.55+0.55+0.35$ (2.60). Leg formula I,IV,III,II. Leg spination: I: Mt v 0-2-1. Remaining legs are without spines. Coloration (in alcohol). Carapace yellow, tinged with brown, with a shiny shagreed surface; the anterior half of the eye field brown and black around eyes. Sternum yellow. Endites and labium yellow, tinged with brown and with white apexes. Chelicerae yellow, tinged with brown. Abdomen: dorsum brownish grey, with a yellow transverse band in its centre and two longitudinal parallel yellow stripes in its front half, dorsum in entirely covered with a brownish shiny scutum; sides brownish grey; venter yellow, without scutum. Book-lung covers yellow, tinged with brown. Spinnerets light yellow. Leg I: Fm, basal half of $\mathrm{Tb}$ and Mt brownish; remaining segments yellow. Legs II-IV entirely yellow. Palps yellow, tinged with brown. Palpal structure as in Figs 17-21: ventral tibial apophysis short, obtuse and slightly bent dorsad; dorsal tibial apophysis think and short, hook-like, directed ventrad; cymbium with a distal-median cut through which some parts of the embolus are visible; functional tegulum pear-shaped; median apophysis nar- 

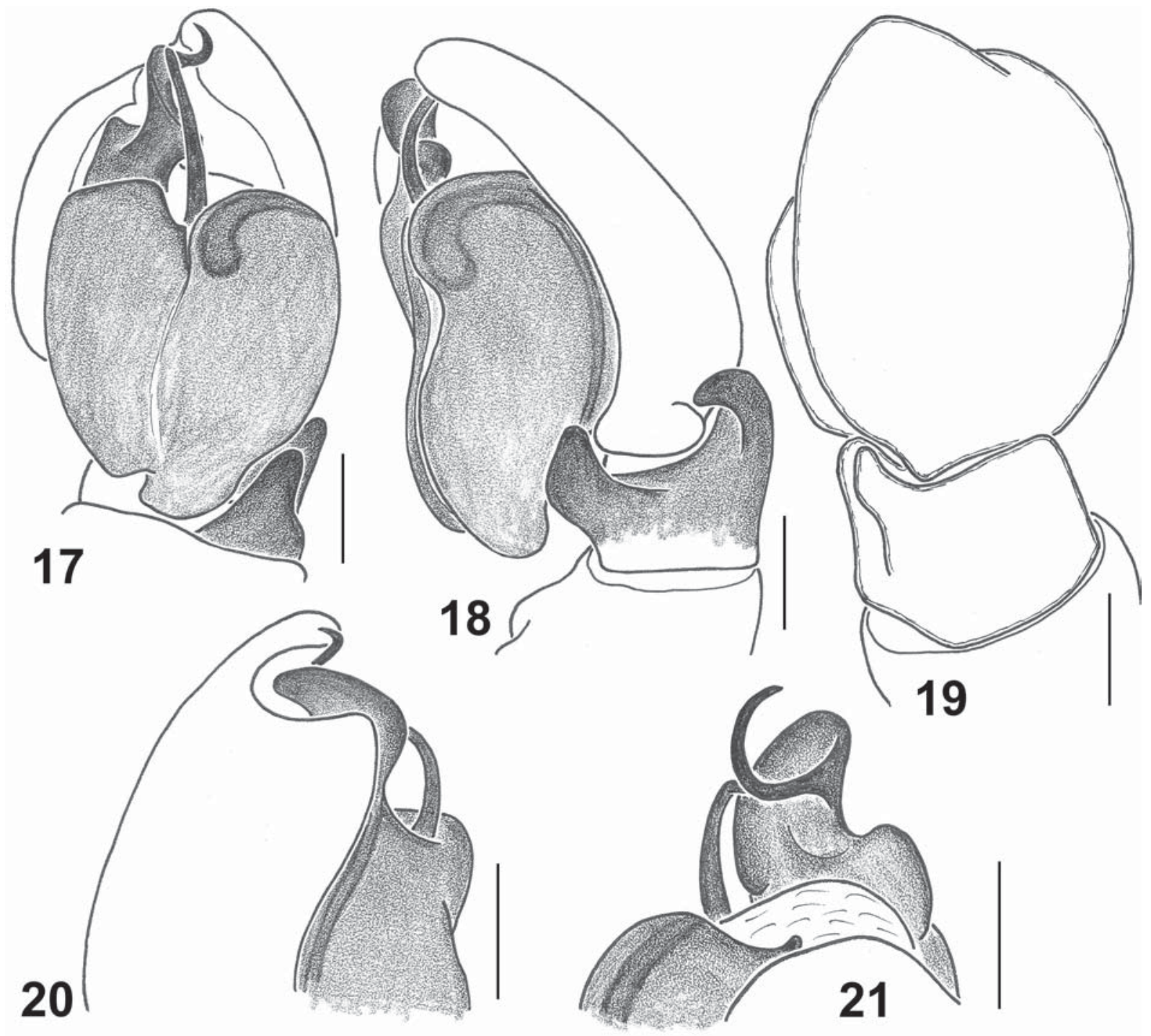

Figs 17-21. Palp of the holotype male of Synagelides munnar sp.n. from India: 17 - ventral view; 18 - retrolateral view; 19 dorsal view; 20 - embolar division, median view; $21-$ ditto, dorsal view. Scale bars $=0.1 \mathrm{~mm}$.

Рис. 17-21. Пальпа самца-голотипа Synagelides munnar sp.n. из Индии: 17 - вид снизу; 18 - вид сзади-сбоку; 19 - вид сверху; 20 - эмболярный отдел, вид медиально; 21 - тоже, вид сверху. Масштаб 0,1 мм.

row blade-shaped, directed anteriad; embolus corkscrew-like, with a wide and heavily-sclerotized basis.

\section{Synagelides palpalis Żabka, 1985 Map.}

Synagelides palpalis Żabka, 1985: 447, figs 573-580 (D $0^{7}+$ ). MATERIAL. VIETNAM: 1 ( Trang Vil. [c. $\left.20^{\circ} 47^{\prime} 19.2^{\prime \prime} \mathrm{N}, 106^{\circ} 59^{\prime} 52.5^{\prime \prime} \mathrm{E}\right]$, summer 1989, T.K. Sergeeva; $5 O^{7} \bigcirc^{7}, 5$ 우 5 juv. (MMUE, G7573.3,75), Tuyen Quang Prov., c. $5 \mathrm{~km}$ east of Na Hang $\left(22^{\circ} 20^{\prime} 59^{\prime \prime} \mathrm{N}, 105^{\circ} 25^{\prime} 36^{\prime \prime} \mathrm{E}\right)$, c. 290 $\mathrm{m}$ a.s.l., beaten from understorey vegetation, 4-13.11.2015, D.V. Logunov.

COMMENTS. The species has been described and known to date from northern Vietnam and SE China (Hainan) only [Żabka, 1985; Song et al., 1999; present data] (Map).
Synagelides palpaloides Peng, Tso et Li, 2002 Map.

Synagelides palpaloides: Logunov, Hereward, 2006: 289, figs $41-45\left(0^{2}+\right)$.

MATERIAL. TAIWAN: $1 \uparrow$ (MHNG), Chayi Co, Alishan Natural Scenic Area [c. $23^{\circ} 30^{\prime} 34.3^{\prime \prime} \mathrm{N}, 120^{\circ} 48^{\prime} 07.1^{\prime \prime} \mathrm{E}$ ], 84th $\mathrm{km}$ of road 18, $2200 \mathrm{~m}$ a.s.1., decaying stump, 8.01.2009, S. Vit; $1 \mathrm{O}^{7}$ (MHNG), same locality, siefting forest litter, 7.01.2009, S. Vit.

COMMENTS. To date, the species has been recorded from Taiwan only [Peng et al., 2002; Logunov, Hereward, 2006; present data] (Map).

Synagelides sumatranus Logunov et Hereward, 2006 Map.

Synagelides sumatranus Logunov et Hereward, 2006: 290, figs 46-52 ( $\left.\sigma^{\top}+\right)$. 


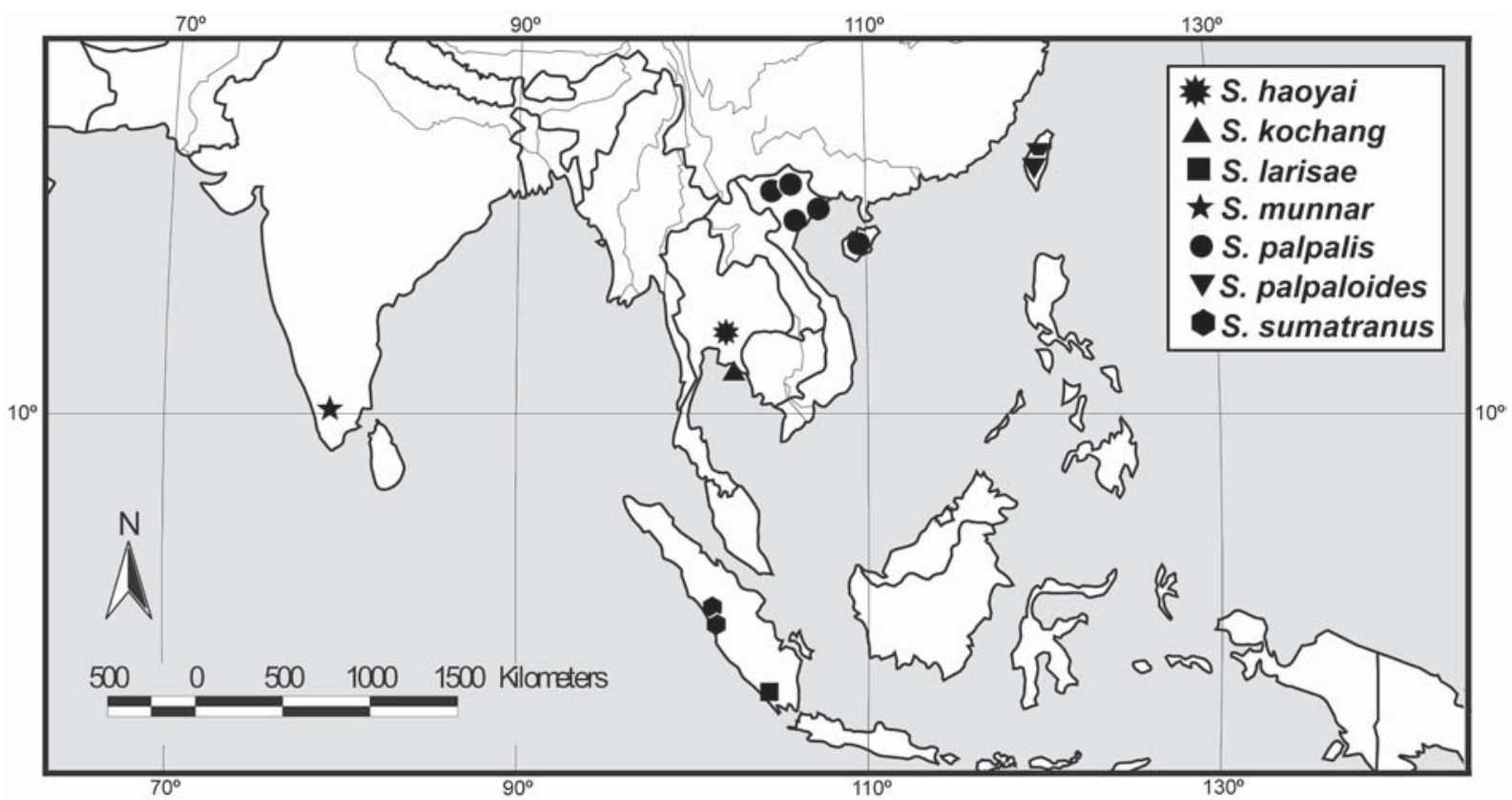

Map. Collecting localities of the Synagelides species studied in the present paper.

Карта. Точки находок видов Synagelides изученных в настоящей статье.

MATERIAL. INDONESIA: $1 \sigma^{7}$ (MHNG), Sumatra, West Sumatra Prov., disturbed primary forest nr. road Lubuksikaping Bonjol, c. $10 \mathrm{~km} \mathrm{~S}$ of Lubuksikaping $\left(0^{\circ} 03^{\prime} 16^{\prime \prime} \mathrm{S}, 100^{\circ} 12^{\prime} 33^{\prime \prime} \mathrm{E}\right)$, $500 \mathrm{~m}$ a.s.1., 12.06.2006, P. Schwedinger; 3 ○ $^{\top}, 3$ + $(\mathrm{MHNG})$, Sumatra, West Sumatra Prov., old secondary forest above Taman Hutan Raya Bung Hatta, nr. road Padang - Lubuksulasih (0 $0^{\circ} 6^{\prime} 45^{\prime \prime} \mathrm{S}$, $\left.100^{\circ} 32^{\prime} 37^{\prime \prime} \mathrm{E}\right), 1100 \mathrm{~m}$ a.s.1., 29-30.06.2006, P. Schwedinger; 1 o (MHNG), Sumatra, West Sumatra Prov., Batang Palapuh Rafflesia sanctuary, c. $12 \mathrm{~km} \mathrm{~N}$ of Bukittinggi $\left(0^{\circ} 14^{\prime} 32^{\prime \prime} \mathrm{S}, 100^{\circ} 21^{\prime} 10^{\prime \prime} \mathrm{E}\right)$, 900-1100 m a.s.1., primary forest, 2-3.06.2006, P. Schwedinger; 1 $\sigma^{7}, 1$ ( 1 (MHN), Sumatra, West Sumatra Prov., Anai Valley, c. 6 $\mathrm{km} \mathrm{S}$ of Padangpanjang $\left(0^{\circ} 28^{\prime} 38^{\prime \prime} \mathrm{S}, 100^{\circ} 21^{\prime} 14^{\prime \prime} \mathrm{E}\right), 500 \mathrm{~m}$ a.s.1., primary forest, 1.06.2006, P. Schwedinger.

COMMENTS. To date, the species has been recorded from Sumatra (Indonesia) only [Logunov, Hereward, 2006; present data] (Map).

\section{Discussion}

The species considered/described in this paper are only provisionally assigned to the genus Synagelides, because all of them are related to those previously placed in Synagelides by various authors. Such taxonomic uncertainty is caused by the more general and yet unresolved problem of interrelationships between the genera Synagelides and Agorius. As was stressed upon by Logunov \& Hereward [2006], both genera might even need to be synonymized.

Recently, Prószyński [2009] made an attempt to reevaluate the status of Agorius and provided the following diagnostic characters thereof based on somatic morphology: patella $\mathrm{I}$ is almost as long as femur I; the presence of a compact group of long spines on the apical-ventral part of tibia I; spines of metatarsi I are unusually long; and abdomen with a clear constriction in both sexes. No diagnostic character of the copulatory organs was mentioned by the latter author.

However, some species which are currently placed in Synagelides display identical diagnostic somatic characters. For instance, S. palpalis and S. palpaloides also have patella I being as long as femur I (see fig. 580 in Żabka [1985]), whereas their copulatory organs are as complex as those in the type species of Synagelides S. agoriformis Strand, 1906 and its closely related species - (cf. figs 268-288 in Bohdanowicz \& Prószyński [1987], figs 573-576 in Żabka [1985] and figs 41-45 in Logunov \& Hereward [2006]). Some other Synagelides species, such as S. cavaleriei (Schenkel, 1963) from China, have a well-marked abdominal constriction (see Prószyński, 2009: figs 14, 15). On the other hand, some Agorius species have a poorly constricted or not constricted abdomen (see Koh \& Ming [2014: 172, 173]), including the generotype of Agorius - A. gracilipes Thorell, 1877 from Indonesia [Prószyński, 2009: fig. 4].

Thus, the Synagelides/Agorius problem requires a special attention in the future, when more species in both genera have been described from both sexes. To date, 50\% species both in Synagelides, and in Agorius remain known from one sex, and the matching of sexes is also problematic in some cases.

ACKNOWLEDGEMENTS. I wish to express my warmest thanks to my colleagues Peter Schwendinger (of the MHNG) and Kirill G. Mikhailov (of the ZMMU) for giving access to the salticid collections of their museums. I also wish to thank the administration of the Joint Russian-Vietnamese Tropical Research and Technological Centre, notably A.N. Kuznetsov and Phan 
Luong, for organizing the field trip to the $\mathrm{Na}$ Hang Nature Reserve (Vietnam), in which specimens of $S$. palpalis were collected.

\section{References}

Bohdanowicz A., Prószyński J. 1987. Systematic studies on East Palaearctic Salticidae (Araneae), IV. Salticidae of Japan // Annales Zoologici, PAN. Vol.41. No.2. P.43-151.

Koh J.K.H., Ming L.T. 2014. Spiders of Borneo, with special reference to Brunei. Kota Kinabalu: Opus publications. 357 pp.

Logunov D.V., Hereward J. 2006. New species and synonymies in the genus Synagelides Strand in Bösenberg et Strand, 1906 (Araneae: Salticidae) // Bulletin of the British Arachnological Society. Vol.13. Pt.8. P.281-292.

Ono H. 1988. A revisional study of the spider family Thomisidae (Arachnida, Araneae) of Japan. Tokyo: National Science Museum. 252 pp.
Peng X.J., Tso I.M., Li S.Q. 2002. Five new and four newly recorded species of jumping spiders from Taiwan (Araneae: Salticidae) // Zoological Studies. Vol.41. P.1-12.

Prószyński J. 2009. Comments on the Oriental genera Agorius and Synagelides (Araneae: Salticidae) // Makarov S.E., Dimitrijeviæ R.N. (eds.). Advances in Arachnology and Developmental Biology. Institute of Zoology, Bulgarian Academy of Sciences Monographs. Vol.12. P.311-325.

Song D.X., Zhu M.S., Chen J. 1999. The Spiders of China. Shijiazhuang: Hebei University of Science and Techology Publishing House, 640 pp.

Żabka M. 1985. Systematic and zoogeographic study on the family Salticidae (Araneae) from Viet-Nam // Annales Zoologici, PAN. Vol.39. No.11. P.197-485.

WSC 2017. World Spider Catalog. Natural History Museum Bern, online at: http://wsc.nmbe.ch, version 18.5 (accessed on October 12th, 2017).

Responsible editor K.G. Mikhailov 